\title{
Neutralization of gas emission on foam-metal catalysts
}

\author{
A.N. Pestryakova ${ }^{a}$, V.V. Luninb ${ }^{b}$, V.P. Petranovskiic ${ }^{c}$ \\ ${ }^{a}$ Department of Inorganic Chemistry, Fritz-Haber-Institute of the MPG, Faradayweg 4-6, 14195 Berlin, Germany \\ ${ }^{\mathrm{b}}$ Chemistry Department, Moscow State University, Moscow 119899, Russia \\ ${ }^{\mathrm{c}}$ Centro de Ciencias de la Materia Condensada, Ensenada 22800, México
}

\begin{abstract}
Catalysts of new structural type - foam metals - have been tested in the process of deep oxidation of hydrocarbons and neutralization of exhaust gases of automotive engines. Foam catalysts have physicochemical, gas-dynamic and catalytic characteristics exceeding the indices of the traditional granular and honeycomb catalysts.
\end{abstract}

Keywords: catalysts, foam metals, neutralization.

\section{Introduction}

Foam materials or high-porosity cellular materials represent a very promising type of structural materials. The extensive investigations of these materials have started only recently. The materials based on foam metals and foam ceramics are produced by doubling the structure of the polymer matrix, especially foam polyurethane, followed by burning out the polymer [1]. The foam materials have a number of interesting, even unique properties, which may be utilized in various areas, especially in heterogeneous catalysis. However, until recently, insufficient attention has been paid to catalysts based on foam materials in comparison with conventional catalytic systems - granulated and blockhoneycomb [2-4].

The aim of this work is to show the efficiency of using catalysts based on foam metals in a number of catalytic processes.

\section{Experimental}

The catalysts were prepared by thermal or chemical deposition of active cover based on Pt, Pd, simple or mixed oxides of transition metals on the foam-metal support. The foam metal $(\mathrm{Cu}, \mathrm{Ni}, \mathrm{Cu}-\mathrm{Ni}$, Nichrome or steel) was coated with the layer of $\gamma-\mathrm{Al}_{2} \mathrm{O}_{3}$ intermediate support in order to increasing the catalyst surface area. Content of Pt or Pd in the neutralisers accounted for $0.5 \mathrm{wt} . \%$, concentration of the transition metal oxides amounted to $10-12 \mathrm{wt} . \%$.

The laboratory experiments were carried out in flowcirculating catalytic system under the following conditions: temperature $-150-350^{\circ} \mathrm{C}$; concentration of the oxidised substance $\left(\mathrm{CO}, \mathrm{C}_{3} \mathrm{H}_{8}\right)$ in gas-air mixture - 1.0 vol.\%; flow rate $0.5 \mathrm{l} / \mathrm{min}$.

Catalytic activity was calculated by the formula:

$\mathrm{W}=\left(\mathrm{C}-\mathrm{C}_{0}\right) * \mathrm{~V} / \mathrm{M}_{\mathrm{kt}}$,

where $\mathrm{V}$ - flow rate $(1 / \mathrm{sec}), \mathrm{M}_{\mathrm{kt}}$ - weight of the catalyst $(\mathrm{g})$, $\mathrm{C}$ and $\mathrm{C}_{0}$ - current and initial concentration of hydrocarbon, respectively $(\mathrm{mol} / \mathrm{l})$.

The foam neutralizers $\left(\begin{array}{ll}1.5 & 1\end{array}\right)$ were also tested on bench carburettor engine at oxygen/(oxidized substance) ratio $=1$. A neutralizer with a volume of 1.51 was installed in a standard system of an exhaust pipe-line at a distance of $1 \mathrm{~m}$ from the exhaust collector. The operating condition of the engine was $800-2600 \mathrm{rpm}$. For comparison the commercial honeycomb neutralizer Pt-containing was tested under the same conditions. 


\section{Results and Discussion}

Physicochemical properties of catalysts based on foam metals

An elementary cell of the foam metal has the form close to a pentadodecahedron (Fig.1). Each node of the cell is characterized by convergence of up to four bridges forming on the whole a three-dimensional network-cellular openporosity frame with the cell packing resembling the densest packing of spheres. This structure ensures a higher degree of bonding and rigidity of the entire structure of the foam metal and anisotropy of the mechanical properties.

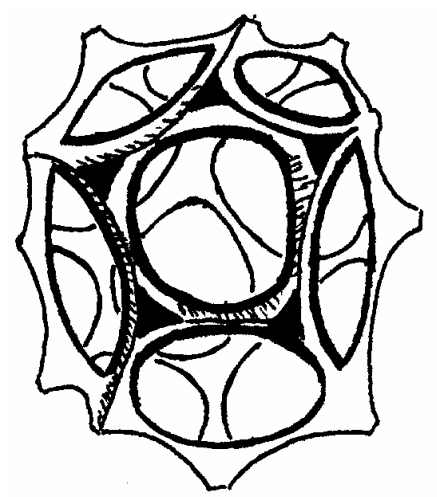

Fig. 1. Elementary cell of the foam metals [1].

The geometrical parameters (mean diameter) of the elementary cells of the frame are determined mainly by the properties of the initial polymer matrix and maybe set in the

range 0.5-5.0 $\mathrm{mm}$. Complete $\mathrm{d}$ foam materials have a higher fraction of the free volume, 80-98 \%. It is thus possible to produce foam metals with a very low volume density, $0.1-0.3 \mathrm{~g} / \mathrm{cm}^{3}$. The last parameters were important for producing catalysts based on foam metals since it enables their material requirements and, consequently, production cost to be greatly reduced.

The initial material for the foam catalyst may be virtually any metal or alloy capable of existing, under normal conditions, in the metallic state, or ceramics of various composition. However, an important characteristic of the catalysts is the value of the specific surface which equals, for pure foam metals, approximately $0.01-0.1 \mathrm{~m}^{2} / \mathrm{g}$. For the majority of catalytic processes, taking place in the kinetic region, this is insufficient to produce active catalysts. Therefore, a number of methods have been developed for increasing the specific surface by direct deposition on the foam support of an oxide catalytically active phase $\left(3-8 \mathrm{~m}^{2} / \mathrm{g}\right)$, using a layer of the intermediate support $\gamma-\mathrm{Al}_{2} \mathrm{O}_{3}(20-50$ $\mathrm{m}^{2} / \mathrm{g}$ ). Low-surface foam metals may be used in hightemperature external diffusion processes.

The high porosity of the foam materials results in their satisfactory gas permeability. Gas-dynamic measurements show that the specific pressure losses in filtration of gases through foam catalysts are comparable with the characteristics of block-honeycomb samples and considerably lower

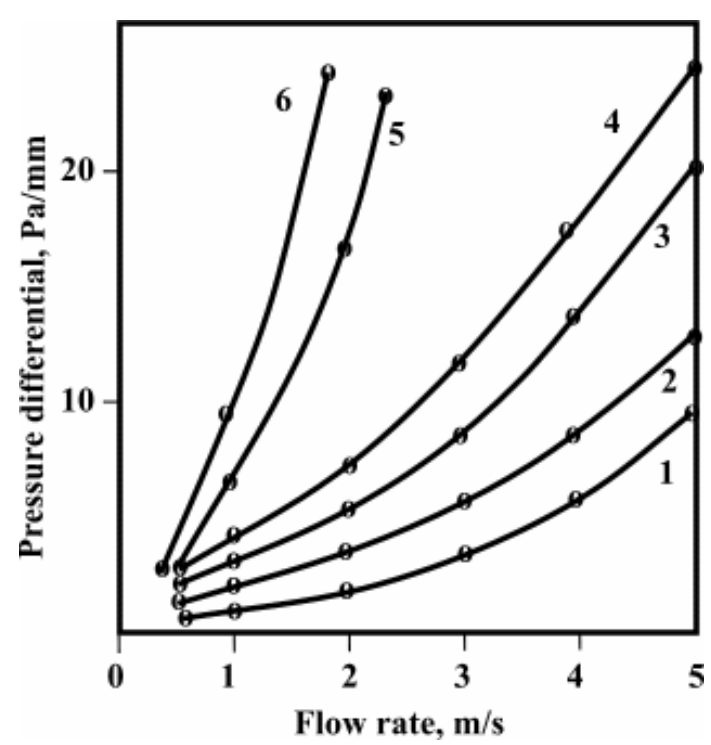

Fig. 2. Gas permeability of the catalysts:

1. foam, cell $2.2 \mathrm{~mm}$

2. honeycomb, cell $2 \times 2 \mathrm{~mm}$

3. honeycomb, cell $1 \times 1 \mathrm{~mm}$

4. foam, cell $0.8 \mathrm{~mm}$

5. granular, $4 \mathrm{~mm}$

6. granular, $2.5 \mathrm{~mm}$

than the parameters of the granulated catalysts, Fig. 2. At the same time, at almost all flow rates of the gas flow, typical of catalytic processes, movement of the gas in foam catalysts takes place in the conditions of separation vortex bypass flow, characterized by a high flow turbulence. This greatly improves the contact of the reaction gas mixture with the surface of the foam catalysts and increases its operating efficiency, whereas in block-honeycomb catalysts part of the molecules passes in the laminar mode without contact with the active surface of the catalyst.

Thus, the investigations show that the foam catalysts have high gas permeability, mechanical strength and structural stiffness so that they can be used efficiently in a number of catalytic processes.

\section{Deep oxidation of hydrocarbons on foam-metal catalysts}

The processes of deep catalytic oxidation of organic compounds are used for purification of gas exhausts of many industrial plants [5]. Conventional catalysts of these processes - granulated and block-honeycomb - have a number of disadvantages reducing their efficiency. The granulated catalysts create a high gas dynamic resistance to the flow, whereas at high flow rates they may mechanically fail as a result of friction between the granules. The honeycomb catalysts have a higher gas permeability but do not always create a sufficient turbulence of the flow. Our previous studies showed a high efficiency of the catalysts based on foam materials in these processes [6-9].

In the process of deep oxidation of n-butane tests were carried out catalysts based on foam materials. Nichrome and 
ceramics are the most durable materials, however, foam ceramic support is too brittle and does not stand the falling weight test. Nichrome and steel supports are the most corrosion-resistant among the foam metals, whereas $\mathrm{Cu}$ and $\mathrm{Cu}$ $\mathrm{Ni}$ are oxidized sufficiently when heated in air.

Catalytic activity of the catalysts containing oxide active phase supported on the foam carrier are presented in the Table 1.

Samples Nos.1-5 (Table 1) contain a layer of the intermediate support $\gamma-\mathrm{Al}_{2} \mathrm{O}_{3}$ on to which the active phase $\mathrm{CuCr}_{2} \mathrm{O}_{4}$ was deposited. The specific surface of the samples was $20-30 \mathrm{~m}^{2} / \mathrm{g}$. The samples No 6-15 were prepared by direct deposition of the oxide active phase on the surface of foam metals by homogeneous deposition of the metal formiates from aqueous solutions. The specific surface of these samples was 3-8 $\mathrm{m}^{2} / \mathrm{g}$. The active phase content of the samples was 10-13 wt.\%. For comparison, tests were carried out under the same conditions on samples of industrial catalysts with the active phase $\mathrm{CuCr}_{2} \mathrm{O}_{4}$ - granulated IK-12-8 and honeycomb PS-5.

The experiments show that the foam catalysts have a high catalytic activity comparable with the activity of the granulated sample and greatly exceeding the characteristics of the block-honeycomb catalysts with the same composition of the active phase (Table 1).

Table 1.Catalytic properties of the foam catalysts $\left(\mathrm{T}=300^{\circ} \mathrm{C}\right)$

\begin{tabular}{|c|c|c|c|c|}
\hline \multirow[t]{2}{*}{ No } & \multirow[t]{2}{*}{ Support } & \multirow[t]{2}{*}{$\begin{array}{l}\text { Active } \\
\text { phase }\end{array}$} & \multicolumn{2}{|c|}{$\begin{array}{c}\text { Activity, } \mathrm{Wx10} \text {, } \\
\text { mole/s }\end{array}$} \\
\hline & & & $\begin{array}{c}\text { Per } 1 \mathrm{~g} \\
\text { of the } \\
\text { catalyst }\end{array}$ & $\begin{array}{c}\text { Per } 1 \mathrm{~m}^{2} \\
\text { of the } \\
\text { surface }\end{array}$ \\
\hline 1. & $\mathrm{Cu}$ & $\mathrm{CuCr}_{2} \mathrm{O}_{4}$ & 9.5 & 0.55 \\
\hline 2. & $\mathrm{Cu}-\mathrm{Ni}$ & $\mathrm{CuCr}_{2} \mathrm{O}_{4}$ & 25.3 & 0.85 \\
\hline 3. & Nichrome & $\mathrm{CuCr}_{2} \mathrm{O}_{4}$ & 21.3 & 1.07 \\
\hline 4. & Steel & $\mathrm{CuCr}_{2} \mathrm{O}_{4}$ & 10.3 & 0.77 \\
\hline 5. & Ceramics & $\mathrm{CuCr}_{2} \mathrm{O}_{4}$ & 14.4 & 0.42 \\
\hline 6. & $\mathrm{Cu}$ & $\mathrm{CuO}-\mathrm{Co}_{2} \mathrm{O}_{4}$ & 24.7 & 5.52 \\
\hline 7. & $\mathrm{Ni}$ & $\mathrm{CuO}-\mathrm{Co}_{2} \mathrm{O}_{4}$ & 29.2 & 7.41 \\
\hline 8. & $\mathrm{Cu}-\mathrm{Ni}$ & $\mathrm{CuO}-\mathrm{Co}_{2} \mathrm{O}_{4}$ & 8.5 & 1.94 \\
\hline 9. & $\mathrm{Ni}$ & $\mathrm{CuO}-\mathrm{MnO}_{2}$ & 7.8 & 1.13 \\
\hline 10. & Nichrome & $\mathrm{CuO}-\mathrm{MnO}_{2}$ & 6.2 & 0.91 \\
\hline 11. & $\mathrm{Cu}$ & $\mathrm{CuO}-\mathrm{NiO}$ & 2.0 & 0.74 \\
\hline 12. & Steel & $\mathrm{CuO}-\mathrm{NiO}$ & 3.2 & 1.12 \\
\hline 13. & $\mathrm{Cu}-\mathrm{Ni}$ & $\mathrm{CuO}-\mathrm{CeO}_{2}$ & 2.2 & 0.33 \\
\hline 14. & Nichrome & $\mathrm{CuO}-\mathrm{CeO}_{2}$ & 2.5 & 0.42 \\
\hline 15. & Steel & $\mathrm{CuO}-\mathrm{CeO}_{2}$ & 2.2 & 0.48 \\
\hline 16. & IK-12-8* & $\mathrm{CuCr}_{2} \mathrm{O}_{4}$ & 31.3 & 0.48 \\
\hline 17. & PS-5* & $\mathrm{CuCr}_{2} \mathrm{O}_{4}$ & 1.2 & 0.12 \\
\hline
\end{tabular}

* Commercial catalysts

At the same time, the gas-dynamic characteristics of the foam catalysts are considerably higher than those of the granulated sample (Fig. 2). The differences in the activity of the foam catalysts are determined by several factors. Primarily, this is associated with the composition of the active phase. For example, the extremely high parameters of the sample No 6 and 7 are caused by the well-known fact of the high catalytic activity of the Co-containing compositions. An important role is also played by the specific surface of the samples. Thus, the catalysts with an intermediate support have a large specific surface (5-10 times larger) in comparison with the samples without the $\mathrm{Al}_{2} \mathrm{O}_{3}$ layer. At the same time, the maximum content of the intermediate support depends on the chemical composition of the foam material. Thus, the nickel is capable of retaining only $7 \mathrm{wt} . \%$ of $\mathrm{Al}_{2} \mathrm{O}_{3}$, ceramics - to $35 \%$.

The foam supports containing the composition metals catalytically active in deep oxidation processes - $\mathrm{Cu}, \mathrm{Ni}, \mathrm{Fe}$, $\mathrm{Cr}$. However, because of a low specific surface area, the activity of pure foam supports is not high and at $400^{\circ} \mathrm{C}$ it is equal to $\left(\mathrm{Wx10}{ }^{2} \mathrm{~mole} / \mathrm{g} \mathrm{s}\right)$ : $0.7(\mathrm{Fe}-\mathrm{Ni}), 0.9(\mathrm{Ni}), 1.5(\mathrm{Cu})$, $2.3(\mathrm{Cu}-\mathrm{Ni})$. However, in deposited catalysts, with no $\mathrm{Al}_{2} \mathrm{O}_{3}$ layer, the material of the foam support has a strong effect on the catalytic process. X-ray phase analysis shows that the surface layer of the foam material during preparation and further operation of the catalysts is partially oxidized, included in the composition of the active phase and takes an active part in the catalytic process.

A serious problem of the foam-metallic catalysts is their corrosion during oxidation reactions which may lead to partial or complete failure of the structure of the support. Therefore, the foam supports based on $\mathrm{Cu}, \mathrm{Cu}-\mathrm{Ni}$ may be used only at low temperatures (below $300^{\circ} \mathrm{C}$ ). However, catalysts based on $\mathrm{Ni}, \mathrm{Ni}-\mathrm{Cr}$, and stainless steel have sufficient corrosion resistance and may be used in hightemperature processes. The intermediate support $\mathrm{Al}_{2} \mathrm{O}_{3}$, also efficiently protects the surface of the catalysts against corrosion.

\section{Catalytic neutralization of exhaust gases of car engines}

Neutralization of the exhaust gases of car engines is an important aspect of protecting the atmosphere of large cities. Conventional neutralizers are ceramic or metallic blocks of a honeycomb structure with a deposited active phase based on noble metals, Pt, Pd, Rh. These catalysts are capable of efficient purification (to 80-90\%) of exhaust gases to remove $\mathrm{CO}$, hydrocarbons and, (when $\mathrm{Rh}$ is added) nitrogen oxide. However, intensive research is still carried out to find methods if increasing the activity of catalysts, their gas permeability and mechanical strength, and also to reduce the content of precious metals. The mechanical and gas-dynamic properties of foam materials indicate that they should be highly effective in this process [8-10]. 


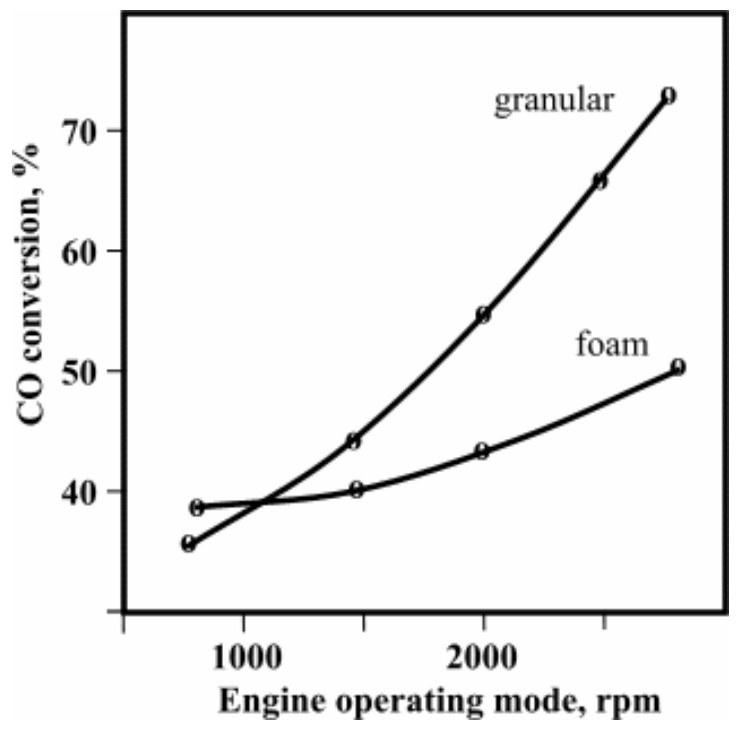

Fig. 3. Efficiency of oxide neutralizers at different engine operating modes

The catalysts based on foam metals were tested in the process of neutralization of the exhaust gases of a stand carburettor engine. Tests were carried out on the samples of foam catalysts containing the active phase based on oxides of non-noble metals, and a Pt-containing foam catalyst with an intermediate support of $\mathrm{Al}_{2} \mathrm{O}_{3}$ (average cell diameter 1.5$2.0 \mathrm{~mm}$ ). Tests were also carried out on a granulated oxide catalyst (granule size 3-4 mm) and an industrial ceramic block-honeycomb Pt-containing neutralizer (cell size 1x1 $\mathrm{mm})$.

Gas-dynamic measurements show that the pressure gradient in the foam catalyst increases by $1-2.5 \mathrm{kPa}$ in comparison with an empty casing. This has no marked effect on the power of the engine. The test results show that the efficiency of the oxide neutralizers is not high (Fig. 3). However, in the conditions in Russia where neutralizers are not used at all, the use of inexpensive oxide catalysts with a mean efficiency of gas cleaning of $60-65 \%$ may prove to be highly promising.

The most interesting results were obtained in testing Pt-containing neutralizers (Table 2). At comparable values of gas permeability, the volume of the catalyst and the content of the expensive metal, the efficiency of foam neutralizers is slightly higher than that of the block-honeycomb sample. It is evident that this is associated with a higher turbulence of the flow in foam catalysts and, correspondingly, with better contact of the gas mixture with the surface of the catalysts. It should be mentioned that the most marked difference in the efficiency of catalysts is at low rotating speeds of the engines and in idle running. As the load on the engine is increased the operating parameters of the catalysts become similar. It is probable that this is caused by a higher thermal conductivity of the metals in comparison with ce- ramics thus causing more rapid heating of the foam catalysts at the start of operation. The degree of oxidation of gases from the nitrogen oxide is not high since the neutralizers did not contain $\mathrm{Rh}$ - effective catalysts of reduction of $\mathrm{NO}_{\mathrm{x}}$.

Table 2. Average conversion degree on the neutralizers (wt.\%)

\begin{tabular}{|c|c|c|c|}
\hline Catalyst & CO & CH & NO $_{\mathbf{x}}$ \\
\hline Foam & 92.4 & 94.7 & 64.9 \\
\hline Honeycomb & 87.2 & 90.1 & 61.0 \\
\hline
\end{tabular}

Since the neutralizers operate under very hard service conditions, the problem of their corrosion resistance is even more important as compared with the catalysts for neutralization of industrial gas emissions. Of course, ceramics has the highest chemical resistance. However, foam-ceramic neutralizers are very brittle and require special measures to protect them against mechanical effects in service of vehicles. Therefore, it is optimum to use foam catalysts based on Nichrome or stainless steel which show satisfactory corrosion resistance during testing. Additional corrosion protection is provided by a layer of an intermediate ceramic support.

\section{Conclusions}

The laboratory tests showed a high efficiency of the supports and catalysts based on foam metals in the processes of deep and selective oxidation. The foam catalysts have high service and catalytic characteristics so that they may be used efficiently. An important fact is the cost of foam metals since foam-metallic catalysts are more expensive than ceramic ones. However, at their low volume density (0.1-0.3 $\mathrm{g} / \mathrm{cm}^{3}$ ) the consumption of the metal is not very high, and the satisfactory mechanical and gas-dynamic properties of foam catalysts enable them to compete efficiently with conventional catalysts. Further examination of the foam catalysts would enable new regions of application of these promising materials in heterogeneous catalytic processes to be found.

\section{Acknowledgements}

The authors acknowledge funding for this research by the grant No MD-344.2003.03 of President of Russian Federation 


\section{References}

[1] Belova S.V. (editor), Porous permeable materials. Handbook, Metallurgiya, Moscow, 1987.

[2] Ketov A.A., Development of oxide cobaltchromium catalysts with a highly permeable cellular structure, Ph D Thesis, Leningrad Technological Institute, Leningrad, 1991.

[3] Fyodorov A.A., High-permeable cellular catalysts. Synthesis and properties, Dr Sc Thesis, DPI, Ekaterinburg, 1994.

[4] Shaposhnikov M.I., Experimental examination of filtration of liquids and gases in high-porosity cellular materials, Perm Polytechnic. Institute, 1990.
[5] Alkhazov T.G. and Margolis L.Ya., Deep catalytic oxidation of organic compounds, Khimiya, Moscow, 1985.

[6] Pestryakov A.N., Fyodorov A.A., Shurov V.A., at al., React. Kinet. Catal. Lett. 1994, 53, pp. 347-352.

[7] Pestryakov A.N., Fyodorov A.A., Gaisinovich M.S., at al., React. Kinet. Catal. Lett. 1995, 54, pp. 167-172.

[8] Pestryakov A.N., Yurchenko E.N., Feofilov A.E. Catal. Today 1996, N 29, pp. 67-70.

[9] Pestryakov A.N., Fyodorov A.A., Devochkin A.N., J. Advanc. Mater., 1994, 5, pp. 471-476.

[10] Pestryakov A.N., Ametov V.A., Rus. J. Appl. Chem. (Engl. Trans), 1994, 67, pp. 306-309. 